\title{
臨床試験における確率化の役割
}

\author{
ファイザー株式会社開発薬事統括部 新 野 伊知郎 \\ 大阪大学大学院医学系研究科 濱 㟝 俊 光 \\ 大阪大学大学院医学系研究科 杉 本 知 之
}

\begin{abstract}
要 旨 臨床試験の基本目的は一般に，将来において検討対象の治療をうけること になる集団に対して適用できる，その治療の情報を得ることにある，確率化は，治 療の比較を前提として，精度と確度の高い情報を限られた資源のもとで効率的に得 るための, 試験デザインの重要な要素の一つである，本稿では，臨床試験における 確率化について, その発展の歴史, 目的々恩恵, そして確率化の正当性に対寸る批判 を整理・概観し，「なぜ確率化を行うか」,「確率化を経て得られるものは何か」,「確 率化の本質は何か」といったことを探る。
\end{abstract}

1.はじめに

・ランダムは「でたらめ」でない(Gaither and Cavazos-Gaither, 1996, p.191)

・汝，確率化なくして解析することなかれ(Senn, 2004)

・『英国のある場所において，1910 年と 1912 年の間で，無作為に選ばれた医師が無作為に疾患 を選定して無作為に診察した患者は，人類の歴史上はじめて, 5 分 5 分の偶然の出会いで得を するよりもよい機会に恵まれた』との H.L. Blumgart (New England Journal of Medicine 270，449-456, 1964) による Lawrence Joseph Henderson(1878-1932)の引用は, 統計家が 確信している過程, 確率化の過程を模倣してからかっている。しかしながら, すべての事柄 は適度に!(Petrie, 1982)

臨床試験は，「ヒト」を対象として実施される，医薬品や医療技術といった治療の有効性と安全性 を検討するための研究である。臨床試験の基本目的は一般に，将来において検討対象の治療をう けることになる(患者)集団に対して適用できる，その治療の情報を得ることにある．具体的には， 治療のどのような(望ましい・望ましくない) 効果が認められるか, 治療の平均的効果はどの程度 の大きさか, 治療の効果は試験対象となった患者についてどの程度まで一様か, 部分集団に抢け る治療の効果はどの程度の大きさか, 得られた治療の効果は規定された枠外の対象に対しても同 様に適用できるかといった問いに対して適切な回答を用意できるように，情報を収集せねばなら ない，そして，その情報は，限られた資源のもとで，精度と確度を高く，かつ効率的に得ることを 要請される。この要請に十分にこたえられるように, プラセボや標準薬などの対照を設定する比 
較試験のデザインでは一般に，(1)偏りを防ぎ，(2)効率の高い比較を保証し，(3)十分な簡便性を備え ることで登録を促進し，(4)誤差を最小にするといったことに最大限の配慮が扔かれる(以降では, 「臨床試験」というとき「何らかの対照を設定する比較試験」をさすこととする)。しかし，臨床試験 において, 試験の実施者が検討の対象となる患者の特性を制御することは極めて困難であり，デザ インで共通に制御できる(唯一の)要因は，「治療」である。このとき，上記の(1)から(4)を達成する ための，デザインの重要な要素として，「確率化」がある。ここに，確率化(Randomized あるいは Randomization)とは，処理を実験単位に偶然性を導入して割り付けることにより，一定の偏りう る系統的䛊差を確率変数とみなせる偶然誤差に転化する行為であり，さらに積極的に系統的誤差 を偶然誤差に転化する行為は確率化操作 (Random Allocation あるいは Random Assignment) と呼ばれる(北川, 1955) 1 。このとき, 臨床試験では, 治療が処理, 患者あるいは被験者が実験単 位に対応する。そして, 臨床試験において, 確率化は, 治療の比較を前提として, それらの比較 可能性を確かなものにするために，既知および未知の因子について，治療効果の比較に影響を及 ほすす「偏り」をできる限り小さくするための唯一で最良の方法である.

現在, 確率化対照試験は, 二つの治療のいずれが優れているかを決定するための科学的に最も 響きのよい接近法であり，医学の進歩に欠くことのできないものとして論じられることがある. これを象徽するように，「科学的根拠に基づく医療」[Evidence-Based Medicine: EBM, Sackett et al. (1997)]の趨勢のなかで, 確率化対照試験は, 臨床研究において治療効果を比較するための 科学的で説得力のある根抛を提供する情報源として最上位に位置づけられている．確率化対照試 験に対する評価は相当に高く，例えば，Tukey（1977）は『ほとんどの種類の内科的治療や外科的 手術の有用性について信頼にたる根拠の情報源は, 適切に計画され注意深く実施された確率化対 照試験である』, Zelen (1979) は『確率化対照試験の崩壤は治療医学の科学的基盤を崩すことにな る』, Smith (1998) は『確率化対照試験は, 20 世紀の医科学において最も意義深い進歩である』と の評洒をくだしている。さらに，Cowan (1981) は，倫理的観点から『ある程度の期待をもって， 非確率化(Non-randomized)試験で患者が何らかの群に参加することは，まったく正当化されず， また倫理性をも損なう：なぜなら，そこから学び得るものは何もないからである」との確信を示し ている．上記のいくらか強い主張は，臨床試験に何らかの形で携わる者のすべてに共通の認識で ないが, その大半の者が少なからず, Byar et al. (1979)の『確率化対照試験は, 依然として治療 の効果を評価するための最も信頼のおける方法である』との見解に賛同するにように思われる.

上記のように，「確率化」は現在，臨床試験を計画・実施し，その結果を評価するうえで，最も 重要で欠くことのできないデザインの要素の一つとして認知され, 当然の行為として疑いなく実 行されている，とくに，臨床試験においては，これまでに多種多様な確率化の方法が独自に提案 され，奏地で活用されている。例えば，代表的で，かつ簡単に利用できるものでも，表 1 に示 す方法があげられる，加えて，これらを実際に遂行できるソフトウェアも整備されている．例え ば, 無償で提供されているものとして, Clinstatや Random Allocation Software では完全確 率化操作 (Complete Randomization) や並べかえ(置換)ブロックデザイン(乱塊法) (Permuted Block Design), Minimでは最小化法(Minimization), Adaptive Randomization では応答適応

\footnotetext{
1 "Randomized" あるいは "Randomization"には,「確率化」,「無作為化」「アンダム化」といった日本語訳があ る. ICH E9 ガイドライン「臨床試験のための統計的原則」(ICH, 1998)の日本語版では, 「無作為化」が作為的 でないとの印象を与え，本来の「確率的要素をもって変動する」の意味を表していないといった理由から，力夕 カナ表記で「ランダム化」を選好している(大橋，2004）。本稿では，できるだけカタカナ表記を避けることを意図 して，以降では一貫して「確率化」を用いる。
} 
表 1. 代表的な確率化の方法

\begin{tabular}{ll}
\hline 方法 & 主要な文献 \\
\hline 完全確率化操作 Complete Randomization Design & \\
確率化割り付げザイン Random Allocation Design & Blackwell and Hodges (1957) \\
打ち切り 2 項デザイン Truncated Binominal Design & Stigler (1969) \\
偏りのあるコインデザイン Biased Coin Design & Efron (1971) \\
並ベかえブロックデザイン Permuted Block Design & Hill (1957), Zelen (1974) \\
つはデザイン Urn Design & Wei (1977, 1978a, b, c) \\
最小化法 Minimization & Pocock and Simon (1975), Taves (1974) \\
\hline
\end{tabular}

型確率化操作(Response-Adaptive Randomization)が装備されている².これらのソフトゥェア は，その他の無償・有償のソフトウェアあるいはサービスと一緒に Dictionary of Randomization Software \& Services ${ }^{3}$ に一覧で表掲されている.

本稿では，これらに加えて何か新しい手法を提案するわけでなく，また既存の方法の特徵や性 能を数值的に評価・比較するわけでない，本稿の目標は，経験豊富な臨床家や統計家には周知の 事実であるが，臨床試験において常識とみなされている確率化について，その発展の歴史，目的 と恩恵，そして確率化の正当性に対する批判を整理・概観し，「なぜ確率化を行うか」，「確率化を 経て得られるものは何か」，「確率化の本質は何か」といったことを改めて探ることにある。なお， 確率化の具体的な実践の仕方や手順, 方法の特徵や性能については, Kalish and Begg (1985), Lachin (1988), Lachin et al. (1988), Rosenberger and Lachin (2002), Hu and Rosenberger (2006), 西 (2006), 上坂 (2006)などを参照されたい.

\section{2. 確率化の発展の歴史}

確率化操作の試行は, 人間の歴史のなかでそれほど古くなく, 比較的, 最近のものである. Stigler (1978) は, 精密で, かつ数学的にも適切な確率化操作の機構で実施された最初の実験として, 物 理学者 Charles Sanders Peirce(1839-1914)とその弟子 Joseph Jastrow (1863-1944)による感覚 器官の闇值を評価する実験での試行 (Peirce and Jastrow, 1885)に言及している.その実験では, 13 枚が赤と 12 枚が黒の 25 枚のカードの組み, 13 枚が黒と 12 枚が赤の 25 枚のカードの組みの, 二つのカードの組みが用意された．そして，1回の試行回数が 25 である実験に対して，これらの 二つのカードの組みが交互に用いられ，二つの処理 (負荷)が割り付けられた．当然の行為として， 割り付けの前に, カードはよく切り混ぜられた. Peirceは, 確率標本が物理的な行為によっての み実際に得られること, 確率標本に基づき帰納的推測を行うには確率化操作を物理的に実施せね ばならないとの確信をもって，この実験を試行していた (Folks, 1984).

上述のように, Peirce and Jastrow (1885) の実験では, 十分に妥当とみなせる確率化操作が 用いられている。しかし，確率化が統計的考え方の一部としてうけいれられるようになったのは， Ronald Aylmer Fisher(1890-1962)により農事試験の枠組みのなかで実験計画の基盤的な原則の

\footnotetext{
${ }_{2}$ Clinstat http://www-users.york.ac.uk/ mb55/soft/soft.htm

Random Allocation Software http://mahmoodsaghaei.tripod.com/Softwares/randalloc.html

Minim http://www-users.york.ac.uk/ mb55/guide/minim.htm

Adaptive Randomization http://biostatistics.mdanderson.org/SoftwareDownload/

3 http://www-users.york.ac.uk/ ${ }^{\sim}$ mb55/guide/randsery.htm
} 
一つとして理論的に体系づけられたことに大きく依っている(Armitage, 1982; Folks, 1984). そ れまで，実験者は，諸種の原因で生じる偏りの影響が無視できるかどうかをもっぱら自らの主観 的判断に委ねていた. Fisherは，穀物に数種の妈理を施したときの影響を評価する農事試験にお いて，それらを散布する区画地に確率化操作を経て割り付けている (Fisher and McKenzie, 1923; Fisher, 1926).この仕方は, 臨床試験において, 例えば, 患者を二つの群にわけ, それぞれの群 で治療が確率化操作にて選定される，いわゆる「群割り付け」(Group Randomization)の仕組み の原型を提供している。

医学研究, とくに臨床試験における「確率化」の成功的な施行と広まりは, 主として Austin Bradford Hill(1897-1991)の唱道と具体的実践によるものである(Armitage, 1982; Harrington, 2000). Hill は, 臨床試験において, 治療間で患者特性の相違として現れうる系統的な偏りを回避 するための唯一の方法として, 治療の確率化割り付けを広めた. その第 1 の成功例が, 最初の近 代的な確率化対照試験として知られる英国医療番議会 (UK Medical Research Council: MRC) による「肺結核の治療に対するストレプトマイシンの臨床試験」(MRC, 1948)である。この試験で は， 7 施設から 15 歳から 30 歳の肺結核の患者 107 例が組みいれられ，それらの患者がストレプ トマイシン群あるいは安静群のいずれかに割り付けられた. Hill は統計家としてこの試験に参画 し，施設每で性別を考慮し確率抽出によりつくりあげた統計的数列を参照しながら，治療を患者 に割り付けている。

その適用の領域は異なるが, 上述のように, Fisher と Hill はともに処理の確率化を現実の場で 具現化し定着させることにおいて重要な役割を果たしている。しかし, 彼らが, この確率化の問 題で互いの論文や著書といった公表物を参照しあうことはほとんどなかった。これは，個人的な 反目や年齢の違い (Fisher は Hill よりも 7 歳年配である)によるものでなく, 単にその適用の領域 が大きく異なっていたことによるらしい(Armitage, 1993).

当然, MRCによるストレプトマイシンの試験よりも前に, 治療の割り付けの方法について, 数 多くの魅惑的な先駆けが存在する.しかし，そこでは共通に，治療の割り付けの機構が偶然性に委 ねられず，むしろ意図的な仕組みで提示される傾向にあった，例えば，ジフテリアに対する血清治 療の試験に扔いて, Fibiger (1898) は二つの治療を交互に患者に割り付ける仕方を試行している. また，Karl Pearson(1857-1936)もこの仕方を腸チフスに対する免疫治療(ワクチン接種)の評洒 (Pearson, 1904)で支持している.Pearson が彼の研究経歴において後に実験計画に（見かけ上） 関心を失ったことを思い起こせば，この事実は相当に興味深い。この仕方の他にも，Amberson et al. (1931) は，肺結核の治療における金チ才硫酸ナトリウムの試験で, van Helmont (1662) が 支持した方法で治療の割り付けを実践している。 それは，二つ以上の比較可能な患者群を構成し， それぞれの群に一つの治療を, コイン投げのような偶然性をともなう行為で配置するものであっ た. 実際に, Amberson et al. (1931) は，24例の患者を，患者の特性の均衡をはかることに十分 に注意を払いながら 12 例からなる二つの群にわけ，それらの二つの群のいずれに実治療とプラセ ボを割り付けるかを「コインをはじくこと」で決定している.しかし，残念ながら，この方法には 患者特性の均衡をはかる際にいくら注意を払ったとしても無視できない未知の要因がはいり込ん でいないことを保証できないといった欠点がある(Armitage, 1982). 


\section{3. 確率化の目的とその恩恵}

Fisher (1926)は, 確率化が, 確率誤差の好ましい推定值と適用しょうとする有意性検定(Test of Significance)の首尾一貫した妥当性を与えることを強調している. Fisher (1950) は, 確率化 について検討することになった契機とその目標について，当時を振りかえり，次のように述べて いる.

『・ロッザムステッド農場の統計部門は，1923 年頃から農業における実験の精度と実験のデ ザインの修正に大変に気を配るようになっている。これによって精度を高く，誤差の妥当な 推定值を与えるという二つの目標を達成しょうとした。・.」

続いて, Fisher (1935) では, 確率化と有意性検定の関係について,『‥すべての有意性検定が妥 当であるために必須の確率化という物理的な行為によって，ある任意のデータ集合に対して，‥ より広範な仮説を検討する手段が与えられているとの認識が欠けているように思える。・目と述べ ている.このとき，この成書の一つの章の題目は，「確率化操作：検定の妥当性の物理的基礎」で ある.

Box and Guttman (1966) は，並べかえブロックデザインといった Fisher 流のデザインでは， 確率化の機構により一つだけでなく多くの要件が満たされるとして，そのデザインを通して具体 的に次の四つの事柄が確実になるとしている.

・関心のあるパラメータの偏りのない推定値が得られる.

・誤差分散の適切な推定値が得られる。

・関心のあるパラメータに関する情報を提供する, 誤差分散と推定值の分散が小さくなる.

・実験そのものの物理的な実施を通して生じる特定の分布理論を，そこから得られる結果の推 論に適用できる。

Folks (1984) は，実験単位に処理を偶然性をもって物理的に割り付けるという行為が, (i) 適用す る解析が何であれ実験の質を改善することに役だつ，(ii）確率モデルに基づく解析を正当化する ことをあげている，この二つの事柄は，Cox (1958)においても，次のように述べられている。

『…あまり統計的でない説明をすると，確率化操作の肯定的な利点は，次の事柄が保証される ことである. a. 大規模実験において推定される処理効果が䛊差として認められる可能性は非 常に小さくなる; b. 推定される処理効果の確率誤差が測定でき, 推定される処理効果の統計 的有意性の水準が吟味できる。・』

上記のような種々の議諭を踏まえて, Harville (1975) は, 次のような要約を与えている.

・確率化操作を行うことにより，必要な仮定が通常の正規理論モデルよりもはるかに制約的で ない, 確率化操作モデル (Randomization Model)に基づいて，好理間の対比に関する推測を 行うことができる.

・確率化をとりいれることで, 試験の計画段階で想定した統計的モデルでとりあげていない要 因が治療間の対比に完全に交絡されてしまうことがほとんどなくなる，その結果，最初に想 定したモデルに欠陥のあることが試験後に判明すれば(例えば，計画段階でそれほど重要でな 
いと考えていた要因が実際には欠かせないものであることが試験後に明らかになった，実験 単位数(標本サイズ)が十分に大きいときに，より適切なモデルに基づいて対比についての推 测を行うことができる。

-確率化操作が行われている場合には，治療間の対比の通常の推定值は不偏であり，信頼領域 と仮説検定は想定したモデルが間違っていても，場合によってはそれらが本来もつ特性を(近 似的に)維持することがある。

・確率化操作をすることにより，試験デザインの選択(例えば，鈎り合い型ブロックデザインに おけるブロックの選定や処理順序の選択) が試験立案者の偏った考え，あるいは先入観や先見 的情報に影響されないことが保証される，その結果，試験立案者が自己欺瞞に陥るのを防ぐ と同時に試験結果を第 3 者にうけいれ易いものとする。

臨床試騃に目を向ければ，Hill (1952) は，MRCのストレプトマイシンの試験に参画した当時 を振りかえり，確率化が保証する事柄として，次の三つをあげている.

-個人の特質(意識的，あるいは無意識の好き嫌い)や調和のとれた判断の欠如が，異なる治療 群の構成にはいり込む余地がないことを保証する。確率化割り付けは, 我々が制御できる守 備範囲になく，群間で不均衡は生じない。

・判断に偏りがあるかもしれず，偏りをとり除くためにそれを考慮しようとつとめたり，また そのようななかで, 過剩に補償しすぎて，「最善を尽くす」ことが別の方向から均衡の欠如を 導くことになったりするような，個人の判断に基づく割り付けについてまわる危険性をとり 去る。

・確率化割り付けを用いることにより，最も厳格な批評家でも，おそらくひいきや愚かさなど から生じた偏りのために認められた群間の差を, 結果を十分に吟味せずに公表したといえな くなる。

これから明らかなように, Hill は, Fisherが繰り返し強く主張した「有意性検定の妥当性」でなく, むしろ客観的にうけいれられる，研究者の判断や結果の信頼性と妥当性を高㖵具として確率 化を捉えている傾向が強い.そして，いくらか軽率な表現であるが，上記の三つの事柄に続けて， Hill (1952) は,『‥忠者が試験に組みいれられるべき適した者であることが決まればただちに，割 り付けの確率化の方法により, 臨床家はすべての責務から解放される。…と述べている。この記 述に, Hill の確率化に対する狙いと期待が集約されている.

Cornfield (1976)は, The University Group Diabetes Program (1970)による試験での失敗 を组上にあげて, 確率化の機能について,『既知の関連する变数を事前につきあわせて均衡させる こと (Matching)やそれらの変数を層別するといった対応の有無にかかわらず，既知・未知のすべ ての変数について比較可能性をほぼ達成する』と述べている. また, Cornfield (1959) は, Pearson (1904)が免疫治療の評価で支持した割り付け法に対するFisherの警告に触れて，臨床試験にお ける確率化の重要性について次のような要約を与えている。

・確率化は, 治療群 (ワクチン接種) と対照群(非ワクチン接種)が, 免疫学的に治療薬の疾患へ の曝露において計算可能な量, あるいは試験の成果に関連するだろう, 実験者にとって既知 や未知の何か別の変数に関して計算可能な量を超えて異なるといった確率を制御する。二つ の群のサイズが大きくなるにともない，この計算可能な差はゼロに向かう. 
・治療が真に効果をもたないとすれば，確率化により，試験の終了時に，いくつの実験におい て，この大きさの差が偶然のみで生じたかに対する回答を用意することができる，数学者が 将来の実験の経過を実際に予測することは神秘的にみえるかもしれない．とり組まねばなら ないことは，所与の数字の組みが二つの群の間ですべての利用可能な方法で偶然性をもって 割りあてられたとすれば，何が起こるかを計算することである，確率化はこれを可能にする．

さらに, Armitage (1982) は, 臨床試験における確率化の利得として, 次の三つをあげている.

・ほほ類似した状況のもとで, 治療が比較できる。

・確率理論の使用を可能にする：これにより，治療間の反応の何らかの差が偶然により生じそ うな範囲を示すことができる。

・確実でないが，プラセボの使用可能性を含めて，治療の識別性を隠すための種々の仕掛けを 可能にする：これは有効性の偏りのない評価に欠くことのできないものである.

いくらか表現に違いはあるが，上記の議論をまとめると，臨床試験における確率化の役割は，治療 群間の比較可能性を確保するために，すなわち治療群が結果に影響を及ぼす既知・未知の要因と 交絡しないように配虑することにあり，具体的な目標として，重要であると考えられる順に，次 のように要約できる。

・臨床試験に絡む予見可能性のはいり达む余地や患者特性の偏りをできる限り小さくし，治潦 群をできるだけ均等に構成すること。

・臨床試験が適正に行われたとき，その結果の再現性を保証すると同時に, 試験結果を第 3 者 にうけいれ易いものとすること。

・統計的推測に必要な確率計算を行うための理論的基盤を与えること.

このとき，農事試験と臨床試験の間で，確率化操作の仕方に大きい違いがあることに留意せねば ならない(Kalish and Begg, 1985; Senn, 2004)。農事試験では，最初に試験に使用する区画が同 定され，次にブロック化の構造が決定され，そして最後にブロック化された区画に処理の割り付 けの配置(パターン)が課せられる。ところが，臨床試験では，ほぼ逆の順序で，治療の割り付け の配置が最初に決定され，次に治療をうけることになる患者が試験の進行とともにみいだされる. そのため，たとえ対象とする患者集団を事前に定義し，その選択と除外の規準を設定することが できたとしても，実際にどの程度まで規準に適合した患者がいあわせるか，そしてそのうちのど の程度の患者が参加に同意するかといった事柄を事前に知り得ることは不可能であり，さらに治 療群がどのような患者集団で構成されるかは試験が終了するまでわからない，加えて，予後につ いても患者間で一様であるとはいえない。このように，臨床試験では農事試験に比較して不確定 で制御が困難な要素が極端に多く，実験計画における確率化の方法を工夫もせずにそのままに手 順どおりに遂行したとしても，Fisher が意図した農事試験での利得や恩恵がそのまま実現される ことはない．臨床試験において，独自に確率化の方法が研究・開発されてきたのは，この理由に よるところが大きい. 


\section{4. 確率化の正当性に対する批判：倫理的観点と統計的観点}

臨床試験で確率化を行うことの利得は大きく，しかも確率化の手順は比較的，簡単であり，実 践できるソフトウェアも開発・整備されている。しかし, 必ずしも, すべての臨床家(医師)や統 計家から「確率化」(あるいは確率化対照試験, とくに検証を主目的としている試験)がうけいれら れているわけでない. その使用, 妥当性や必要性に対して, 大きく二つの観点からの批判, すな わち倫理的観点と統計的観点からの批判がある. 前者の代表的意見として, 患者と直接にかかわ る臨床家がある患者について治療 $A$ が治療 $B$ より選好されるとの確信をもっているときに, 治療 $A$ と治療 $B$ の選択が偶然の行為をもって決められることを許容できるかといった, 臨床家の倫理 観にかかわるものがあげられる (Armitage, 1982; Royall, 1991). 臨床家は，臨床試験において， 治療の効果を評価する研究者であり，また同時に目前の患者を治療する医師でもあるため，目前 の患者の治療, あるいは仮説的な患者集団の将来の治療に関する情報の獲得のいずれを優先させ るかといった倫理的ジレンマに陷ることは避けられない. Weinstein (1974) は, 確率化の利得と 確率化を被験者に強いることについて，次のように主張している.

『…確率化㹥数ある統計手法のなかでも価值のあるものであり，それは他の方法で解決し得な

い問題を解決するが, しかし, 代替法と比較して, その長所は限定的であることを主張した い.そして, 確率化を被験者に強いるという重大な犠牲を考虑すれば，確率化の利得がその 犠牲にまさるかどうかを吟味することは絶対に避けられない. ‥」

また，Davis (1975)は，確率化対照試験が倫理的である状況について，次のように言及している.

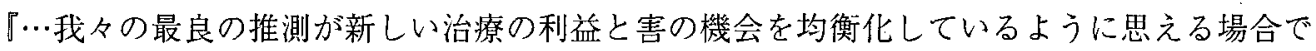
ある: $\cdots 』$

上記の議論を踏まえると，評価対象となる治療のどれもが患者にとって同等の利得をもつ，あるい はどの治療が選好されるといったことが偽りなく不確かであることが確率化対照試験の計画・実 施の前提の一つでなければならない(Byar, 1991; Freedman, 1987)。この考え方は，場合によっ て「不確かさの原則 (Uncertainty Principle)」と呼ばれることもあるが，そこでは集団としての不 確かさでなく，個々の患者での不確かさが重視される.より具体的な患者選択の実践規範として， Peto and Biagent (1998) は，『試験の担当医師が当該の試験治療のどれがその特定の患者に対し て最も適切かを実質的に判断できないときに限り，その患者を試験に組みいれることができる』と の手引きを示している，上記の原則あるいは規範にのっとって患者の選択が行われてはじめて， 臨床試験において確率化が倫理性と相反せずに共存できる土台が築かれるように思われる4.この とき, Hill (1963) は, 臨床家と患者の関係に対する統計家の態度として, 彼の経験から, 次の教 訓を与えている。

『‥臨床試験における臨床家とのつきあいから, 統計家が, 臨床家一患者の関係と臨床家が直 面する現実的で特有の倫理的問題をよりよく理解すれば，実験的にあまり理想的でないが， 何らかの価値，おそらく医学への無視できない価值をもっていそうな試験に対し工夫を施す

\footnotetext{
4 本稿では触れないが, このような倫理的問題への対処として, 患者選択の実践規範とは別に, 試験そのものに工 夫を施す仕方が提案されている. 例えば，Palmer and Rosenberger (1999)を参照.
} 
ことに手を貸せることを学習した，‥上り重要なこととして，統計家自身が患者をみること はないが..., それでもやはり統計家は、はるか遠くにいて，オリュンポスの神々のように, 気 楽にすべての責任からのがれて，肘掛け椅子に腰をかけていることができないことを学習し た．努力の結集の協力者として，その責任は統計家にも残らず共有されよう。…』

上記の倫理的観点からの批判に加えて,「確率化」の科学的正当性を主張し, その寒践を推進し ているようにみえる統計家のなかにも，批判・異論を唱える者は少なくない[例えば, Harville (1975), Neyman and Pearson (1937), Pearson (1937, 1938), Savage (1962)などを参照 $]^{5}$. とくに，患者に治療を偶然性をもって割り付けることで, 試験がどの程度まで改善されるかに疑 いをもつ者は多く(Folks, 1984), 実際に改善の程度や確率化が成功裏に運んだことを首尾よく確 かめることは容易でない，例えば，確率化が行われたとしても，そこに選択による偏りが入り込 んでいないことを事後的にデータで示すことは不可能に近い．また，Fisher は確率化操作によっ て検定の妥当性の基整が与えられると保証しているにもかかわらず，それがどのように保証され るかを納得のいく形で具体的に明らかにしていない，これについて, Folks (1981)は, 次のよう に述べている.

『…確率化操作によって，どのようにして検定の妥当性の基礎が与えられるかは明らかでな い.扔そらく心理的なものであろう。純粋に数学的なものでない，‥」

また，Harville (1975)は）ヒトを対象とした試験を除いた議論であることを断ったうえで(基本 的に, 制御可能な実験の場を想定している), 確率化をKiefer (1959) が詳述した最適実験デザイ ン法と对比し, 実験単位, ブロック因子および処理の釣り合いのとれたFisher 流の試験デザイン は最適デザインであり，確率化は数多く用意された最適デザインのなかから一つのデザインを選 定することに奇与しているにすぎないと主張し，(i) 確率化が推測において確率化操作モデルを使 用することを正当化しない，(ii) 確率化操作モデルに基づく推測には欠点がある，(iii）実験者が 実験で使用する素材の性質をよく理解し，この知識を賢く利用して試験をデザインすれば，交絡 の生じる可能性は確率化を用いずとも小さくできる，(iv）実験者に公正を期すことを要求しなが ら，代替の方法を用いても実験者の意困や先入観がデザインの選択にはいり込まないようにでき るといった事柄[議論の詳細は Harville (1975) を参照]を列挙して, 確率化の必要性について次 のように結論づけている.

『‥確率化操作の使用に帰せられている利点のいくつかは幻想であり，他の利点は最適デザイ ン法によっても確率化操作よりもよくとはいわないまでも同程度には得られる。…』

他方, Box et al. (1978)は, 確率化が統計的推測に不可欠であるとして, 次のように述べている.

『‥Fisher は，この一見して打ち勝ち難い笨地から脱出する仕方を示している．実験自体の 物理的な実行の一部として確率化操作を導入することで，未知の㩖乱要因(Disturbance)の 形状の如何にかかわらず，推測手順を妥当なものにすることができる。・州

また, Bayes 流解析の視点から, Rubin (1978) と Lindley and Lovick (1981) は, 確率化操作に

\footnotetext{
${ }^{5}$ Kempthorne (1977)は,これらの批判・異論者を，(a) 神秘化され断定的でない Bayes 流派あるいは新 Bayes 流派, (b) 確率化の概念は馬鹿げているという立場をとるBayes 流派, (c) 類似の立場をとる非 Bayes 統計家の 三つに分類している。
} 
ついてそれぞれ次のような肯定的な見解を示している.

『‥強固な事前の知識がある状況において, 確率化は重要でないかもしれない。・しかしなが ら，研究のデザインや解析に対する統計家の注意を向けさせることに十分な程度に，処理の 因果効果が捉え難いとき，二三の関連のある共変量を記録することは難しく，また，それら の変数と従属变数との関係は不完全にしか理解されないであろう. 健康科学や社会科学でお 馴染みのそのような状況において, 古典的な確率化デザインは事前の規定(Specification)に 対する妥当な Bayes 流解析の感度を劇的に減少させ，そのような解析の計算を大いに簡易に することから, Bayes 流派の統計家にとって必須の道具であると考えられるに違いない， ..1

『‥自分たちのデザインにとって $T$ (処理)と $A$ (要因)の効果が交絡しないことを合理的に確 実にするために，㚮理 $T$ を偶然性をもって，すなわち $A$ と独立に割り付けることができる. これによって, 交絡のないことが保証されるわけでないが, 交絡の可能性が受容できる水準

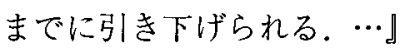

臨床試験に目を向ければ, 確率化に対して, 比較的, 好意的な見方が多い. 例えば, Royall (1991) は, 計画的な確率化が妥当な統計的推測が拠り所とする確率分布をつくりたすとの観点から, 確 率化の必要性を次のように強調している。

『‥確率化の原則は，確率化対照試験がまさに望ましいものであり，しかも科学的に必要性が 高いものであるといった信念を抱かせる一つの重要な要素である.これは，その原則が, 非 確率化研究から統計的に妥当な推測が不可能であることを含意するためである。‥」

このときっこのような意見に対する経験的な反論として, Benson and Hartz (2000)や Concato et al. (2000) は，冠動脈疾患や肺結核に対寸る治療の検討のために実施された確率化対照試験と それに対応する観察研究 (コーホート研究や症例-対照研究などの観察研究)のメタ・アナリシスの 結果の比較から, 慎重に計画・実施された観察研究が確率化対照試験に比して好ましく，しかも そのような研究が(確率化を用いないことから)倫理的に可能な唯一の研究となることを主張して いる(van Belle, 2002)。また, Gilbert (1974) は，確率化の必要性と作用について，次のように 主張している。

『‥型どおりの確率化以外の過程が患者を治療群と対照群を割り付けることに使用されると き，その結果が治療でなく割り付けによるといったことを否定することに，決して確信をも てない，すなわち確率を評価できない。…確率化の本来の作用は，研究者の意図と責務を明 確にする．参加者の同意はこれを，おのおのの被験者がリスクを共有し結果に寄与するよう な，努力の結集にかえる，而」

Lindley and Lovick (1981)の見解にみられるように, 確率化は, 試験の開始前で, 臨床試験の 計画，実施，解析扔よび結果の評価と関連する因子の影響を回避できる可能性を高めることに確 実に役だつ.しかし，『汝，確率化することなくして解析することなかれ』に代表される確率化の 擁護を踏まえれば，試験を終えデータを目前にして確率化が行われたことを知り得たとして，実 行する解析においてどのような利得があり，利得があるとすれば解析においてどのように活かす ベきか. 
多数の研究者によって様々な視点から確率化の意味づけがなされているが[例えば, Kempthorne (1977) を参照]，筆者らの知る限りでは，これまでに支持者・批判者の双方の誰もが納得のいく 結論は得られてないようである。このような議論があるにもかかわらず，「確率化」が継続して臨 床試験で用いられるのは，(筆者らを含めて)臨床試験に携わる者の大半が, 次の Folks (1982)に 似た思いを抱いているからであろうか。

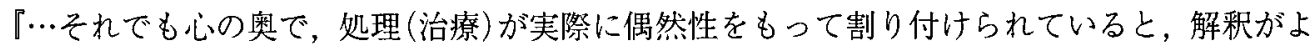

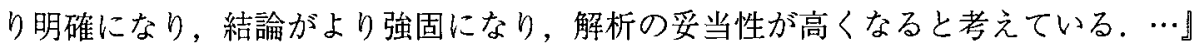

\section{5. 結びに代えて}

最近, 筆者の 1 人は, 治験審査委員会や臨床研究審査委員会の委員として, そこに諮られる臨 床試験の計画書を科学的かつ倫理的な観点から吟味・評価する機会が劇的に多くなった。それら の数件で, 確率化操作の仕方について，気にかかる記述や仕様が認められた，それらは，例えば, 並べかえブロックデザインにおいてブロックサイズを明らかにしたり，小規模の試験にもかかわ らず多くの予後因子を考虑して層別割り付けを実施したり，また最小化法などの積極的に治療間 で予後因子の均衡をはかる割り付けを実施したにもかかわらず，解析ではそれらの影響を評価し ないといったものであった。これらはいずれも，既報の文献[例えば, Senn (2004) や上坂 (2006) を参照]やICH-E9 ガイドラインなどで，そのとり扱いについて注意が喚起されている事柄であ る.そして，それらの計画書では共通に，その計画立案者が確率化に過度の信頼を拉いているか， あるいは確率化を単に「決まりごと」として実施しているように感じられた。

確かに，臨床試験において確率化を適用することにより，試験開始の患者特性などに関連して 生じる偏りが，完全でないが結果に影響を及ほさない程度までに小さくすることができる，しか し，例えば，確率化を経て，治療に割り付けられた何例かの患者が途中で治療を拒否したり，手 続き上の間違いや複雑な試験方法からの逸脱のために，その治療をほとんどうけないといった， 運営上の偏りにつながる事象が数多く発生すれば，折角の確率化操作の苦心を無駄にしてしまう ことになる，確率化に加えて，当初の計画通りにほぼ欠陥なしに試験を遂行できるような工夫を 試験デザインや運営方法に盛り込むことが極めて重要である。このとき, Harville (1975) は確率 化の必要性と研究者の科学的精神について次のように述べている.

『…研究者が真の科学的精神をもってデザインの問題にとり組み, 公正を期することに全力を 尽くせば，確率化が行われている場合と同様に心配する必要がないように思われる．逆に， 研究者にこのような精神がまったくなければ，実験結果に多大の信頼を扔くことはできない であろう。・...

この Harvilleの科学的精神を心に留めて，「確率化さえ行えば」といった確率化に過度の信頼をお く姿勢を省み，確率化を実践することが望まれる，とくに，統計家は，適用する統計的方法やそ こから得られる結果と解釈に対して説明責任を負っており（前谷，2002），(確率化に限ったことで ないが臨床試験にかかわる統計的知識をもちあわせていない者に対して「なぜ確率化を行うか」, 「確率化により何が達成されるか」，「確率化を行うときに注意すべきことは何か」といった事柄を， 要請の有無にかかわらず十分に説明し協力を働きかけることが理想的な姿勢のように思われる. 
最近, EBMの旗のもとに，「観察的(Observational)」という用語は，「実験的 (Experimental)」 でない, 否定的な研究を示す冠語として用いられ，「観察研究」はその代表として，そこから得ら れる結果はほとんど意義をもたないかのように論じられることがある．このとき，実騟研究とは， 対象に積極的に働きかけてある条件(処理)を与えたときに，対象がどのように振る舞うかを追跡 する「試行」あるいは「検証」を目標とする研究である．他方，観察研究とは，ある実験の方式に従っ て人間母集団の特性間の関係の検討を主題とし，「処理」が偶然性をもって割り付けられていない 群を比較する類の研究である。これらから明らかなように, 観察研究と実験研究を区別する二つ の研究の大きい違いは，そこに確率化をともなう介入があるかどうかである. 確かに, 実験研究 に基盤をおく確率化対照試験は，Byar et al. (1976)が主張するように「治療の有効性を評価する ための最も信頼できる方法」であるが，これは決して観察研究に代表される確率化を用いない方法 が科学的価值をもたないといったことを意味しない(Royall, 1991). 確率化対照試験と観察研究 の違いは，「正当な科学」と「不当な科学」「真実」と「偽り」の違いで説明されるものでない(Freid， 1974). 例えば, 疫学では, 概して確率化された対照群を設定することはできないが, それにも かかわらず健康科学に役だつ知見を依然として見いだしている．医薬品の臨床評価の過程におい ては，実験研究を第一義とするにしても，そこから得られる結果が楽観的でないか，過大評価(あ るいは過小評価)でないかといった歯どめが必要である。確率化対照試験は，検証したい一つの 仮説(場合によっては，複数のこともあるが)に対して最適化され，(悪くいえば) 評価に都合のよ い限られた患者のみを対象とすることから，その結果の適用範囲は決して広くない。むしろ，医 療の現場で真に必要とされる情報は，実験研究よりも観察研究から得られると感じられる場面に 往々にして遭遇する(後藤・濱㟝，2005）．承認後の市販後評価に位置つけられる第 IV 相 [製造販 売後 (市販後) 臨床試験]では，第 I 相から第 III 相で得られた集団情報の確認的側面に加えて，よ り適応的で実際的な現場での治療の用い方を知ることが一つの主要な目標に揭げられている。こ れは，観察研究によらねば成し得ない。このようにみれば，実験研究と観察研究は反目する関係 になく，むしろ互いに補いあう関係にある。医薬品の臨床評価では，何らかの新しい発見・知見 を得て，それを検証・評価する過程を前提として，「探索」と「検証」の段階が交互に繰り返される のが常であり，医薬品評価に携る者として，観察研究と実験研究のそれぞれの役割と関係を十分 に理解し諸種の問題に対応・対処したい(後藤・濱崎, 2005). とくに, 統計家は, 医学研究にお ける確率化対照試験と非確率化対照試験の実際の貢献とともに，それらの長所と短所を指摘する ことで，医薬品開発や試験の計画と運営に対してよりよい支援を行うことができるし，また支援 せねばならない。

最後に，次の二つの引用をもって本稿を結びたい.

・観察者は自然に耳を傾け，実験家は自然に問いかけ，そしてその問いを明らかにするために 自然に働きかける(Bernard, 1865)

・確率化がなけば，そこに真実はないといった人を惑わせるような仮定に基ついて仕事を続け るべきでない(Freid, 1974)

謝 辞 本稿の構成に際し，丁寧な査読を通して貴重なご指摘とご意見を頂戴した審査員と編集 委員の諸先生方に心から謝意を表します。また，研究の機会と場を与えてくださった大阪大学大 学院医学系研究科の大野ゆう子先生に心から感謝いたします。さらに, 現場の医師の立場から患 
者のための医療について鋭い問題提起と勇気ある提案をされていることに対し，日頃のご指導と 併せて, 大阪大学大学院医学系研究科の佐古田三郎先生に深䓕の敬意と謝意を捧げます。な拉, 本稿をまとめるにあたり，文部科学省科学研究費基盤研究 B(一般）「テーラーメイド医療実現に 向けての統計的基盤技術の開発と研究」(研究代表者：大瀧 慈), 扝よび統計数理研究所 平成 18 年度重点型研究「生物統計学の深化と展開」(研究代表者：柳本武美)の援助をうけた。

\section{参 考 文 献}

Amberson, J.B., Jr., McMahon, B.I. and Pinner, M. (1931): A clinical trial of sanocrysin in pulmonary tuberculosis. American Review of Tuberculosis 24, 401-435.

Armitage, P. (1982): The role of randomization in clinical trials. Statistics in Medicine 1, 345-352.

Armitage, P. (2003): Fisher, Bradford Hill, and randomization. International Journal of Epidemiology 32, 925-928.

Benson, K. and Hartz, A.J. (2000): A comparison of observational studies and randomized, controlled trials. New England Journal of Medicine 342, 1876-1886. Discussion in (2000) 342, 1907-1909 \& 343, 1194-1197.

Bernard, C. (1865): Introduction a l'étude de la médecine expérimentale. Paris: J.B. Bailliere.

Blackwell, D. and Hodges, J.L., Jr. (1957): Design for the control of selection bias. Annals of Mathematical Statistics 28, 449-460.

Box, G.E.P., Hunter, W.G. and Hunter, J.S. (1978): Statistics for Experiments. New York: John Wiley \& Sons.

Box, G.E.P. and Guttman, I. (1966): Some aspects of randomization. Journal of the Royal Statistical Society B24, 543-558.

Byar, D.P. (1991): Comment on "Ethics and statistics in randomized clinical trials" by R.M. Royall. Statistical Science 6, 65-68.

Byar, D.P., Simon, R.M., Friedewald, W.T., Schlesselman, J.J., DeMets, D.L., Ellenberg, J.H., Gail, M.H. and Ware, J.H. (1976): Randomized clinical trials: Perspective on some recent ideas. New England Journal of Medicine 295, 74-80.

Concato, J., Shah, N. and Horwitz, R.I. (2000): Randomized, controlled trials, observational studies, and the hierarchy of research design. New England Journal of Medicine 342, 1887-1892. Discussion in (2000) 342, 1907-1909 \& 343, 1194.

Cornfield, J. (1959): Principle of research. American Journal of Mental Deficiency 64, 240-252.

Cornfield, J. (1971): The university group diabetes program: A further statistical analysis of the mortality findings. Journal of the American Medical Association 217, 1676-1687.

Cox, D.R. (1958): Planning of Experiments. New York: John Wiley \& Sons.

Cox, D.R. (1982): A remark on randomization in clinical trials. Utilitas Mathematica 21A, 245-252.

Cowan, D.H. (1981): The ethics of trials of ineffective therapy. IRB: A Review of Human Subjects Research $3,10-11$.

Davis, M.D. (1975): Applications of the principles of clinical trials. American Journal of Ophthalmology 79, $779-785$.

Efron, B. (1971): Forcing a sequential experiment to be balanced. Biometrika 58, 403-417.

Fibiger, J. (1898): Om serumbehandlung of Difiteri. Hospitalstidende 6, 309-325, 337-350.

Fisher, R.A. (1926): The arrangement of field experiments. Journal of the Ministry of Agriculture 33, 503-513.

Fisher, R.A. (1935): The Design of Experiments. Edinburgh: Oliver \& Boyd.

Fisher, R.A. (1950): Author's Note to Paper 17 in Contributions to Mathematical Statistics. New York: John Wiley \& Sons.

Fisher, R.A. and McKenzie, W.A. (1923): Studies in crop variation II: The manurial response of different potato varieties. Journal of Agricultural Science 13,311-320.

Folks, J.L. (1981): Ideas of Statistics. New York: John Wiley \& Sons.

Folks, J.L. (1984): Use of randomization in experimental research. Experimental Design, Statistical Models, and Genetic Statistics, ed. by K. Hinkelmann, Chap.3, 17-32, New York: Marcel Dekker. 
Freedman, B. (1987): Equipoise and the ethics of clinical research. New England Journal of Medicine 317, $141-145$.

Fried, C. (1974): Medical Experimentation: Personal Integrity and Social Policy. Amsterdam: NorthHolland.

Gaither, C.C. and Cavazos-Gaither, A.E. (1996): Randomness. Statistically Speaking: A Dictionary of Quotations, 191-192, London: Institute of Physics Publishing.

Gilbert, J.P. (1974): Randomization of human subjects. New England Journal of Medicine 291, 1305-1306.

後藤昌司・濱㟝俊光 $(2005)$ : 医学統計学の標榜. 感染・炎症・免疫 $35,65-82$.

Harville, D.A. (1975): Experimental randomization: Who needs it? American Statistician 29, 27-31.

Harrington, D.P. (2000): The randomized clinical trial. Journal of the American Statistical Association 95, $312-315$.

Hill, A.B. (1952): The clinical trial. New England Journal of Medicine 247, 113-119.

Hill, A.B. (1963): Medical ethics and controlled trials. British Medical Journal i, 1043-1049.

Hu, F. and Rosenberger, W.F. (2006): The Theory of Response-Adaptive Randomization in Clinical Trials. New Jersey: John Wiley \& Sons.

International Conference on Harmonisation of Technical Requirements for Registration of Pharmaceuticals for Human Use (1998): ICH Topic E9: Statistical Principles for Clinical Trials

[厚生労働省 (1998): 臨床試験のための統計的原則。医薬審第 1047 号，平成 10 年 11 月 13 日] (http://www.nihs.go.jp/dig/ich/efficacy/e9/e9step4.pdf).

Kalish, L.A. and Begg, C.B. (1985): Treatment allocation methods in clinical trials: A review. Statistics in Medicine 4, 129-144.

Kempthorne, O. (1977): Why randomize? Journal of Statistical Planning \& Inference 1, 1-25.

Kiefer, J. (1959): Optimal experimental designs. Journal of Royal Statistical Society B21, 272-319.

北川敏男 (1955): 実験計画法講義 I：基礎編 (1). 培風館.

Lachin, J.M. (1988): Properties of simple randomization in clinical trials. Controlled Clinical Trials $\mathbf{9}$, $312-326$.

Lachin, J.M., Matts, J.P. and Wei, L.J. (1988): Randomization in clinical trials: Conclusions and recommendation. Controlled Clinical Trials 9, 365-374.

Lindley, D.A. and Novick, M.R. (1981): The role of exchangeability in inference. Annals of Statistics 9, $45-48$.

前谷俊三 (2002): Neyman-Pearson 統計学から新しい臨床統計学へ：エビデンスより説明責任を。天理医学紀要 $5,100-116$.

Medical Research Council (1948): Streptomycin treatment of pulmonary tuberculosis. British Medical Journal 2, 769-782.

Neyman, J. and Pearson, E.S. (1937): Note on some points in "Student's" paper on "Comparison between balanced and random assignments of field plots". Biometrika 29, 380-388.

西 次男 (2006): 無作為化. 臨床試験ハンドブック，丹後俊郎・上坂浩之編, 137-155, 朝倉書店.

大橋靖雄 (2004): 臨床統計学：臨床試験を中心として．数理科学 489, 60-67.

Palmer, C.R. and Rosenberger, W.F. (1999): Ethics and practice: Alternative designs for phase III randomized clinical trials. Controlled Clinical Trials 20, 172-186.

Pearson, K. (1904): Report on certain enteric fever inoculation statistics. British Medical Journal 2, 12431246.

Pearson, E.S. (1937): Some aspects of the problem of randomization. Biometrika 29, 53-64

Pearson, E.S. (1938): Some aspects of the problem of randomization II: An illustration of "Students" inquiry into the effect of "balancing" in agricultural experiment. Biometrika 30, 159-179.

Peirce, C.S. and Jastrow, J. (1885): On small differences of selection. National Academy of Science Memories $3,75-83$.

Peto, R. and Baigent, C. (1998): Trials: The next 50 years. British Medical Journal 317, 1170-1171.

Petrie, A. (1982): Why randomization is essential and how to do it. The Randomized Clinical Trial and Therapeutic Decisions, eds by N. Tygstrup and J.M. Lachin, New York: Marcel Dekker.

Pocock, S.J. and Simon, R. (1975): Sequential treatment assignment with balancing for prognostic factors in the controlled clinical trials. Biometrics 31, 103-115.

Rosenberger, W.F. and Lachin J.M. (2002): Randomization in Clinical Trials. New York: John Wiley \& Sons.

Royall, R.M. (1991): Ethics and statistics in randomized clinical trials. Statistical Science 6, 52-88. 
Rubin, D.B. (1978): Bayesian inference for causal effects: The role of randomization. Annals of Statistics 6, $34-58$

Sackett, D.L., Richardson, W.S., Rosenberg, W. and Haynes, R.B. (1997): Evidence-Based Medicine: How to Practice and Teach EBM. London: Churchill-Livingstone.

Savege, L.J. (1962): The Foundations of Statistical Inference. London: Methuen \& Company.

Senn, S. (2004): Added values: Controversies concerning randomization and additivity in clinical trials. Statistics in Medicine 23, 3729-3753.

Smith, R. (1998): Fifty years of randomized controlled trials. British Medical Journal 317, 1166.

Stigler, S.M. (1969): The use of random allocation for the control of selection bias. Biometrika 56, 553-560.

Stigler, S.M. (1978): Mathematical statistics in the early stages. Annals of Statistics 6, 239-265.

Taves, D.R. (1974): Minimization: A new methods of assigning patients to treatment and control groups. Clinical Pharmacology \& Therapeutics 15, 443-453.

The University Group Diabetes Program (1970): A study of the effects of hypoglycemic agents on vascular complications in patients with adult-on-set diabetes. Diabetes 19, 747-830.

Tukey, J.W. (1977): Some thoughts on clinical trials, especially problems of multiplicity. Science 198, $679-684$.

上坂浩之 (2006): 無作為化とその方法. 郜床試験の計画と解析, 59-69, 朝倉書店.

van Belle, G. (2002): Statistical Rules of Thumbs. New York: John Wiley \& Sons.

van Helmont, J.B. (1662): Qriatrike or Physik Refined. London: Lodowick Loyd.

Wei, L.J. (1977): A class of designs for sequential clinical trials. Journal of the American Statistical Association $72,382-386$.

Wei, L.J. (1978a): The adaptive biased coin design for sequential experiments. Annals of Statistics $\mathbf{6}$, 92-100.

Wei, L.J. (1978b): A class of treatment assignment rules for sequential experiments. Communication in Statistics: Theory \& Methods 7, 285-295.

Wei, L.J. (1978c): An application of an urn model to the design of sequential controlled clinical trials. Journal of the American Statistical Association 73, 559-563.

Weinstein, M.C. (1974): Allocation of subjects in medical experiments. New England Journal of. Medicine 291, 1278-1285.

Zelen, M. (1974): The randomization and stratification of patients to treatment and control groups. Journal of Chronic Disease 27, 365-375.

Zelen, M. (1979): A new design for randomized clinical trials. New England Journal of Medicine 300 , $1242-1246$. 


\title{
The Role of Randomization in Clinical Trials
}

\author{
Ichiro Arano $^{1}$, Toshimitsu Hamasaki ${ }^{2, *}$ and Tomoyuki Sugimoto ${ }^{2}$ \\ ${ }^{1}$ Pfizer Japan Inc. \\ ${ }^{2}$ Osaka University Graduate School of Medicine
}

\begin{abstract}
The major objective of a comparative clinical trial is to unambiguously identify (or not) a treatment effect and assess its magnitude. Random allocation of treatments is essential in designing a trial to achieve the objective efficiently under limited resources. The history, role, issues, and controversies surrounding the application of random allocation in clinical trials are reviewed. In conclusion, the reasons why random allocation is necessary and essential in clinical trials are discussed. Furthermore, the reasons why random allocation is necessary and essential in clinical trials are discussed.
\end{abstract}

Key words: Austin Bradford Hill, comparability, evidence-based medicine, medical ethics, randomized controlled trial, Ronald Aylmer Fisher, uncertainty principle.

${ }^{*}$ Corresponding author

(Toshimitsu Hamasaki)

Received February 13, 2007; Received in final form April 25, 2007; Accepted April 25, 2007. 